\title{
RESPONSE OF AFRICAN EGGPLANT (SOLANUM MACROCARPON L.) TO FOLIAR APPLICATION OF 6-BENZYLAMINOPURINE AND GIBBERELLIC ACID
}

\author{
Jelili T. OPABODE*, Simbiat OWOJORI \\ Obafemi Awolowo University, Department of Crop Production and Protection \\ 220005, Ile-Ife, Nigeria
}

Received: February 2018; Accepted: February 2019

\begin{abstract}
The influence of foliar application of benzylaminopurine (BAP) and gibberellic acid $\left(\mathrm{GA}_{3}\right)$ alone and in combination on quantitative and qualitative yields of Solanum macrocarpon L. 'Igbagba' was investigated to increase the production of the vegetable. Treatments were arranged in randomized complete block design with three replicates. Analysis of variance showed that treatments had significant $(\mathrm{p}<0.05)$ influence on all parameters measured. Foliar application of $20-40 \mathrm{mg} \cdot \mathrm{dm}^{-3}$ of $\mathrm{GA}_{3}$ alone doubled the shoot heights compared with other treatments. The highest leaf area, fresh shoot weight, dry weight and number of regrowth was observed on plants to which foliar application of $40 \mathrm{mg} \cdot \mathrm{dm}^{-3}$ of BAP and $30 \mathrm{mg} \cdot \mathrm{dm}^{-3} \mathrm{of}$ $\mathrm{GA}_{3}$ was applied. Combinations of $40 \mathrm{mg} \cdot \mathrm{dm}^{-3}$ of BAP and $30-40 \mathrm{mg} \cdot \mathrm{dm}^{-3}$ of $\mathrm{GA}_{3}$ produced the highest quantities of chlorophyll a and chlorophyll $\mathrm{b}$, carotenoids, total phenolics, soluble sugars and soluble protein. Highest moisture, crude protein, crude fat and ash contents were detected when $40 \mathrm{mg} \cdot \mathrm{dm}^{-3}$ of BAP and $10-40 \mathrm{mg} \cdot \mathrm{dm}^{-3}$ of $\mathrm{GA}_{3}$ were applied. However, the application of $\mathrm{GA}_{3}$ alone promoted crude fiber and carbohydrate synthesis. Leaf $\mathrm{Na}, \mathrm{P}, \mathrm{Ca}, \mathrm{Mg}, \mathrm{Zn}$ and $\mathrm{Fe}$ had highest quantities when $40 \mathrm{mg} \cdot \mathrm{dm}^{-3}$ of BAP was combined with $30-40 \mathrm{mg} \cdot \mathrm{dm}^{-3}$ of $\mathrm{GA}_{3}$. Leaf $\mathrm{K}$ was promoted by the application of BAP alone and combination of $40 \mathrm{mg} \cdot \mathrm{dm}^{-3}$ of BAP and $10-20 \mathrm{mg} \cdot \mathrm{dm}^{-3}$ of $\mathrm{GA}_{3}$. The highest number of re-growth was observed when $40 \mathrm{mg} \cdot \mathrm{dm}^{-3}$ of BAP was combined with $30 \mathrm{mg} \cdot \mathrm{dm}^{-3}$ of $\mathrm{GA}_{3}$. Foliar application of $40 \mathrm{mg} \cdot \mathrm{dm}^{-3}$ of BAP and $30 \mathrm{mg} \cdot \mathrm{dm}^{-3}$ of $\mathrm{GA}_{3}$ in combination was suggested for the enhancement of quantitative and qualitative yields of the vegetable.
\end{abstract}

Keywords: external application; leaf vegetable; plant growth regulation; 'Igbagba'

\section{INTRODUCTION}

African eggplant is an important indigenous African leafy vegetable. It is a tropical perennial crop that originated in West Africa. The crop is also cultivated in Central and East Africa, Caribbean, South America, and some parts of Southeast Asia. Solanum macrocarpon can grow to a height of 1-1.5 m. It has an alternate leaf pattern with the blade width of $4-15 \mathrm{~cm}$. The shapes of the leaves are oval and lobed with a wavy margin. The vegetable is raised from seeds, which are sown in a nursery with $20 \mathrm{~cm}$ space between the rows. The seedlings are transplanted into the field when they are 4-6 weeks old at a spacing of $50 \times 50 \mathrm{~cm}$ (Schippers 2000).

The importance of $S$. macrocarpon as a vegetable is mainly derived from its high nutritive and food values of its leaves, which make it a popular soup condiment in West Africa. Fresh leaves and young stems of $S$. macrocarpon are widely consumed in West Africa and Central Africa (Schippers 2000). Leaves can be harvested for a number of seasons and sometimes for more than a year when not interrupted by a dry season. According to Schippers (2000), the leaves consist of $86 \%$ water, $6 \%$ carbohydrates, $4.6 \%$ protein, $1.6 \%$ fibers and $1 \%$ fat. Oboh et al. (2005) reported that unprocessed leaves of $S$. macrocarpon 
had $4.3 \%$ protein, $0.6 \%$ fat, $1.4 \%$ crude fiber, $1.3 \%$ ash, $89.7 \%$ moisture, $32.6 \mathrm{mg} \cdot \mathrm{kg}^{-1} \mathrm{Ca}$ and $8.2 \mathrm{mg} \cdot \mathrm{kg}^{-1}$ $\mathrm{Zn}$. Research revealed that the leaves of the vegetable contains $14.0 \%$ glutamic acid, $13.3 \%$ aspartic acid, 7.5\% leucine and 6.6\% arginine (Schippers 2000). Medicinal properties of the vegetable are being exploited to cure many human and animal diseases in Africa and Asia. For example, in Sierra Leone, mature leaves of the vegetable are heated and chewed to ease throat pain. In Kenya, decoctions made from the roots are used to treat hookworms (Schippers 2000). Furthermore, the root of S. macrocarpon is a part of the herbal mix for curing bronchitis, body aches and asthma, and for speeding up the process of healing wounds. During the screening of the leaf cuticular waxes from two cultivars of S. macrocarpon, an unusual profile with elevated sterols and low hydrocarbon contents was detected, suggesting that the plant is producing phytosterols (Haliński et al. 2012).

Despite its nutritional and medicinal importance, production of the vegetable falls short of demand throughout the year (Adebooye \& Opabode 2004). This is attributed to slow growth and regeneration caused by limited axillary bud formation by the vegetable (Owojori 2017). External application of plant growth regulators (PGRs), to augment internally secreted ones, is a viable method of increasing yield, re-growth and quality of S. macrocarpon (Opabode \& Adebooye 2005). Studies have established that cytokinin- and gibberellins-driven diversion of assimilates and mineral nutrients toward shoot meristems, rather than to roots, resulted in an increase in aerial biomass in a wide number of species (Di Benedetto et al. 2015). As a result, 6-benzylaminopurine (BAP; a cytokinin) and $\mathrm{GA}_{3}$ (gibberellic acid) have been externally applied to promote the growth, development and quality of crop species, including vegetables. For example, exogenous benzylaminopurine supplied to pot-grown rooted-cuttings of Epipremnum aureum (an ornamental plant) resulted in the promotion of shoot development, leaf area growth and fresh and dry weights accumulation (Di Benedetto et al. 2013). A single foliar application of $50 \mathrm{ppm}$ of $\mathrm{GA}_{3}$ increased plant height, number of leaves, number of fruits, fruit weight, ascorbic acid and total soluble solids of tomato (Kumar et al. 2014).
Foliar application of $\mathrm{GA}_{3}$ substantially boosted stem elongation, number of leaves per plant, number of pods per plant, number of seeds per pod, seed weight and seed yield in okra (Ayyub et al. 2013).

The production of safer and healthy vegetables using sustainable and environmentally friendly agricultural practices plays a vital role in determining their market value and nutritional benefits. In this context, the risk factors related to foliar application of PGRs and product safety are increasingly investigated. To ascertain the dietary intake risk of PGRs residues in vegetables (pepper, tomato and potato), PGR residues in vegetables was monitored and the acute risk assessment was developed by Shan et al. (2015). The authors found that pesticide residue of PGR in vegetables was very low, in the range of 0.0109-0.182 $\mathrm{mg} \cdot \mathrm{kg}^{-1}$, and PGR are safe for use on vegetables. Similarly, PGR residue of 96 fruits on which PGRs were applied was investigated by Liu et al. (2016). The results were evaluated according to maximum residue limits (MRLs) by the Chinese regulation. The short-term risk of external application of PGRs was below $3.25 \%$ and the long-term risk was also very low, ranging from $0.0005 \%$ to $0.4302 \%$ and the PGRs considered safe for use on fruits (Liu et al. 2016). The response of $S$. macrocarpon to the external application of BAP and $\mathrm{GA}_{3}$ is not known. The objective of this study was to determine the influence of foliar application of BAP and $\mathrm{GA}_{3}$ applied alone and in combination on growth, physiological parameters, proximate content and mineral element composition of pot-grown S. macrocarpon.

\section{MATERIALS AND METHODS}

The study was conducted at the greenhouse of the Faculty of Agriculture, Obafemi Awolowo University, Ile-Ife, Nigeria. Seeds of the vegetable were provided by Dean of the Faculty, Professor D.J. Oyedele. Four-weeks old uniform and healthy seedlings raised in the nursery were transplanted singly in polyethylene pots containing $500 \mathrm{~g}$ of a rich loamy soil with a $\mathrm{pH}$ of 7.2 and cation exchange capacity of $15.3 \mathrm{cmol} \cdot \mathrm{kg}^{-1}$. Each plant was irrigated manually, and daily, with $800 \mathrm{ml}$ of tap water, with a $\mathrm{pH}$ of 6.8. To check the reproducibility of the results, the study was repeated. 


\section{Treatments and experimental design}

Plants were treated with foliar application of BAP $\left(10,20,30\right.$ or $\left.40 \mathrm{mg} \cdot \mathrm{dm}^{-3}\right)$ and $\mathrm{GA}_{3}(10,20,30$ or $40 \mathrm{mg} \cdot \mathrm{dm}^{-3}$ ) alone and in combinations at 2 and 4 weeks after transplanting with an atomizer at sunset. The surface tension of $\mathrm{GA}_{3}$ solution was reduced by the addition of $0.5 \%$ Tween-20. Treatments were arranged in a randomized complete block design with 3 replicates. Fifteen plants were used per treatment. Data on survival, number of leaves per plant, leaf area, shoot height, fresh shoot weight and dry weights were recorded at 12 weeks after transplanting. Measurement of physiological parameters

Pigments were extracted from fresh leaves $(1 \mathrm{~g})$ with $80 \%$ acetone following homogenization. The homogenized mix was separated by centrifugation at $5000 \times \mathrm{g}$ for $10 \mathrm{~min}$. Absorbances of the supernatant were read with a spectrophotometer at wavelengths of $645,653,662$ and $664 \mathrm{~nm}$ for chlorophyll a and chlorophyll $\mathrm{b}$ and $470 \mathrm{~nm}$ for carotenoids, (Lichtenthaler \& Wellburn 1985). Measurements were performed in triplicate.

Total phenolics content was determined from $0.5 \mathrm{~g}$ of fresh leaves, which was ground in $80 \%$ acetone $(10 \mathrm{ml})$ following Julkunen-Tiitto (1985). The homogenate mix was collected. After that a mix of Folin-Ciocalteu reagent $(1 \mathrm{ml})+\mathrm{H}_{2} \mathrm{O}(2 \mathrm{ml})+$ the supernatant $(0.1 \mathrm{ml})$ was homogenized, followed by vigorous shaking. To it, $5 \mathrm{ml}$ of $\mathrm{Na}_{2} \mathrm{CO}_{3}(20 \%)$ was added and the volume was brought to $10 \mathrm{ml}$ using distilled $\mathrm{H}_{2} \mathrm{O}$. Absorbance was recorded at $750 \mathrm{~nm}$.

Total soluble proteins were determined in $0.25 \mathrm{~g}$ of fresh leaves ground in $10 \mathrm{ml}$ of $50 \mathrm{mM}$ of potassium phosphate buffer ( $\mathrm{pH}$ 7.8). Samples were centrifuged at $10,000 \times \mathrm{g}$ at $4{ }^{\circ} \mathrm{C}$ for $15 \mathrm{~min}(\mathrm{Brad}-$ ford 1976). An $0.1 \mathrm{ml}$ aliquot was mixed with $2 \mathrm{ml}$ of Bradford reagent, and the absorbance read with a spectrophotometer at $590 \mathrm{~nm}$.

To measure total soluble sugars, $0.1 \mathrm{~g}$ of fresh green leaves was ground in $10 \mathrm{ml}$ of an $80 \%$ ethanol solution and shaken for $6 \mathrm{~h}$ at $60^{\circ} \mathrm{C}$. The supernatant $(0.1 \mathrm{ml})$ was mixed in anthrone reagent $(3 \mathrm{ml})$. The mixture was heated for $10 \mathrm{~min}$, ice cooled and incubated for $20 \mathrm{~min}$. Absorbance was recorded at $625 \mathrm{~nm}$ with a spectrophotometer. Total soluble sugars were determined from a standard curve of glucose (Yemm \& Willis 1954).

\section{Determination of proximate contents}

Moisture, ash, crude fat, crude fat and crude fiber were determined in accordance with the official methods of the association of official analytical chemists (AOAC 1999), whilst nitrogen was determined by the micro-Kjeldahl method (Pearson 1976) and the percentage of nitrogen was converted to crude protein by multiplying by 6.25 . Carbohydrate was determined by difference.

\section{Determination of mineral element}

To analyze for leaf mineral composition, $5 \mathrm{~g}$ of dry milled samples was ashed in a furnace at $550{ }^{\circ} \mathrm{C}$ for $12 \mathrm{~h}$. The ash was cooled in desiccators and weighed. Two milliliters of concentrated hydrochloric acid was added to dissolve the ash, along with a few drops of nitric acid (AOAC 1990). The solution was evaporated to almost dryness in a boiling water bath. The content was transferred to $100 \mathrm{ml}$ volumetric flash and diluted to mark with deionized water. A PU9000 atomic adsorption spectrophotometer (Pye Unicam Ltd, Cambridge, UK) with acetylene flame was used to determine the presence of phosphorus, calcium, magnesium, zinc and iron (AOAC 1990). Sodium and potassium contents were determined using an AIM 049000 flame photometer (Aimil Ltd, New Delhi, India).

\section{Statistical analysis}

Data were subjected to one-way analysis of variance using PROC GLM in SAS (ver. 6, SAS Inc., Cary, NC). Means were separated using Duncan's multiple range test at $5 \%$ level of probability.

\section{RESULTS AND DISCUSSION}

Foliar application of BAP alone and in combination with $\mathrm{GA}_{3}$ significantly ( $p<0.05$ ) influenced number of leaves, shoot height, leaf area, fresh shoot weight, dry weight and number of re-growth (Table 1). Previous reports have shown that a single spray of $50 \mathrm{mg} \cdot \mathrm{dm}^{-3}$ of BAP on some leaf vegetables during the first days after emergence increases total leaf area, fresh weight and dry weights (Coro et al. 2014; Di Matteo et al. 2015). Exogenous application of $\mathrm{GA}_{3}$ improves vegetative and reproductive phases of growth of tomato, okra, and cabbage (Ayyub et al. 2013; Kumar et al. 2014; Pal et al. 2016, Saddon \& Al-Zubaidy 2017; Owojori 2017). The number of re- 
growth increased slightly when the concentration of BAP was increased. However, the number of regrowth was not increased when the concentration of $\mathrm{GA}_{3}$ was increased. The highest number of re-growth was observed when $40 \mathrm{mg} \cdot \mathrm{dm}^{-3}$ of BAP was combined with $30 \mathrm{mg} \cdot \mathrm{dm}^{-3}$ of $\mathrm{GA}_{3}$. It is possible that exogenous BAP stimulated rapid cell division, differentiation and enlargement of meristematic cells resulting in early formation of shoot buds observed in the treated cuttings. Gibberellic acids stimulate cell elongation and expansion during plant growth and development (Yamaguchi 2008). It is possible that combination of BAP and $\mathrm{GA}_{3}$ as foliar spray resulted in massive cell division, differentiation and shoot bud growth. Plants that received foliar application of BAP or $\mathrm{GA}_{3}$ alone had similar number of leaves, which was higher than that in control plants. However, plants treated with foliar application of $40 \mathrm{mg} \cdot \mathrm{dm}^{-3}$ of BAP and $30 \mathrm{mg} \cdot \mathrm{dm}^{-3}$ of $\mathrm{GA}_{3}$ had highest number of leaves. Plants treated with foliar application of $20-40 \mathrm{mg} \cdot \mathrm{dm}^{-3}$ of $\mathrm{GA}_{3}$ had the highest shoot height, which nearly doubled the shoot heights of other treatments. $\mathrm{GA}_{3}$ is known for the growth enhancement by cell division, stem elongation and inter-node elongation (Taiz \& Zeiger 2002; Owojori 2017; Ayyub et al. 2013). Leaf area of plants that received foliar application of $\mathrm{BAP}$ or $\mathrm{GA}_{3}$ alone were similar and lower than that of plants treated with foliar applications of BAP and $\mathrm{GA}_{3}$ in combination. The highest leaf area was observed on plants treated with foliar application of $40 \mathrm{mg} \cdot \mathrm{dm}^{-3}$ of BAP and $30 \mathrm{mg} \cdot \mathrm{dm}^{-3}$ of $\mathrm{GA}_{3}$. Foliar application of BAP and $\mathrm{GA}_{3}$ in combination produced the largest fresh shoot weight. There was no difference in the fresh shoot weight of plants treated with $\mathrm{GA}_{3}$, which were higher than fresh shoot weight of BAP and control plants. Similarly, the highest dry weights were obtained from plants that received foliar applications of BAP and $\mathrm{GA}_{3}$ in combination. The dry weights of plants treated with $\mathrm{GA}_{3}$ were not significantly $(p>0.05)$ different. In this study, high contents of chlorophyll a, chlorophyll $\mathrm{b}$ and carotenoids were responsible for the high number of leaves, leaf area, fresh shoot weight, dry weight, total phenolics, soluble sugars and proteins when BAP and $\mathrm{GA}_{3}$ were applied in combination. This is because chlorophyll a, chlorophyll $b$ and carotenoids are photosynthesis pigments responsible for light harvesting for assimilate production, which is used for the development of leaves, leaf area, fresh shoot weight and dry weight and for the synthesis of phenolics, soluble sugars and proteins.

Foliar application of BAP alone and BAP and $\mathrm{GA}_{3}$ in combinations significantly $(\mathrm{p}<0.05)$ influenced the chlorophyll content, carotenoids, total phenolics, total soluble sugars and total soluble proteins (Table 2). Chlorophyll a and chlorophyll b syntheses were highest in plants that received foliar applications of $40 \mathrm{mg} \cdot \mathrm{dm}^{-3}$ of BAP and $30-40 \mathrm{mg} \cdot \mathrm{dm}^{-3}$ of $\mathrm{GA}_{3}$ in combination, which were twice more than double chlorophyll a and chlorophyll $b$ of the control plants. As the concentration of BAP increased, the content of chlorophyll a was also increased. Whilst the content of chlorophyll a did not differ significantly ( $p>0.05$ ) amongst $\mathrm{GA}_{3}$ treatment, chlorophyll $b$ did not differ significantly ( $p>0.05)$ amongst both $\mathrm{BAP}$ and $\mathrm{GA}_{3}$ treatments. The contents of carotenoids were highest in plants that received foliar applications of $40 \mathrm{mg} \cdot \mathrm{dm}^{-3}$ of BAP and $30-40 \mathrm{mg} \cdot \mathrm{dm}^{-}$ ${ }^{3}$ of $\mathrm{GA}_{3}$ in combination, which were more than twice of those of chlorophyll a and chlorophyll b of the control plants. In the BAP-alone treatments, the contents of carotenoids were increased when the concentration of BAP was increased, whereas carotenoids did not respond to an increase in the concentration of $\mathrm{GA}_{3}$. Foliar application of BAP in spinach has been reported to elevate the content of chlorophyll a, chlorophyll $b$, carotenoids, total soluble protein and malondialdehyde (Aslam et al. 2016). The highest quantity of total phenolics was produced by plants treated with $\mathrm{BAP}$ and $\mathrm{GA}_{3}$ in combination, irrespective of their concentrations. Total phenolics increased when the concentration of BAP was increased. Total phenolics did not respond to $\mathrm{GA}_{3}$ increment. The highest quantity of total soluble sugars was produced by plants treated with $40 \mathrm{mg} \cdot \mathrm{dm}^{-3}$ of BAP and 20 $40 \mathrm{mg} \cdot \mathrm{dm}^{-3}$ of $\mathrm{GA}_{3}$ in combination. Total soluble sugars did not respond to both BAP and $\mathrm{GA}_{3}$ treatments. Foliar application of $40 \mathrm{mg} \cdot \mathrm{dm}^{-3}$ of BAP in combination with $40 \mathrm{mg} \cdot \mathrm{dm}^{-3}$ of $\mathrm{GA}_{3}$ produced more than twice the quantity of total soluble protein produced by control plants. An increase in the concentration of BAP increased the total soluble protein, whereas total soluble protein did not respond to an increase in the concentration of $\mathrm{GA}_{3}$. 
Table 1. Influence of external application of $\mathrm{BAP}$ and $\mathrm{GA}_{3}$ on re-growth parameters of $S$. macrocarpon

\begin{tabular}{cccccccc}
\hline $\begin{array}{c}\mathrm{BAP} \\
\left(\mathrm{mg} \cdot \mathrm{dm}^{-3}\right)\end{array}$ & $\begin{array}{c}\mathrm{GA}_{3} \\
\left(\mathrm{mg} \cdot \mathrm{dm}^{-3}\right)\end{array}$ & $\begin{array}{c}\text { Number of } \\
\text { leaves }\end{array}$ & $\begin{array}{c}\text { Shoot height } \\
(\mathrm{cm})\end{array}$ & $\begin{array}{c}\text { Leaf area } \\
\left(\mathrm{cm}^{2} \text { per plant }\right)\end{array}$ & $\begin{array}{c}\text { Fresh shoot } \\
\text { weight } \\
(\mathrm{g} \text { per plant })\end{array}$ & $\begin{array}{c}\text { Dry weight } \\
(\mathrm{g} \text { per plant })\end{array}$ & $\begin{array}{c}\text { No of } \\
\text { re-growth }\end{array}$ \\
\hline 0 & 0 & $10.5 \pm 2.3 \mathrm{~d}$ & $6.5 \pm 2.2 \mathrm{~d}$ & $25.8 \pm 4.9 \mathrm{~d}$ & $37.2 \pm 5.6 \mathrm{e}$ & $6.4 \pm 1.8 \mathrm{~d}$ & $2.3 \pm 1.8 \mathrm{e}$ \\
10 & 0 & $17.5 \pm 3.6 \mathrm{c}$ & $15.1 \pm 2.7 \mathrm{c}$ & $43.0 \pm 5.2 \mathrm{c}$ & $56.8 \pm 6.7 \mathrm{c}$ & $43.4 \pm 3.5 \mathrm{~b}$ & $4.4 \pm 1.5 \mathrm{~d}$ \\
20 & 0 & $16.7 \pm 3.2 \mathrm{c}$ & $14.5 \pm 2.7 \mathrm{c}$ & $46.4 \pm 5.2 \mathrm{c}$ & $58.6 \pm 5.7 \mathrm{c}$ & $42.3 \pm 3.5 \mathrm{~b}$ & $4.5 \pm 1.5 \mathrm{~d}$ \\
30 & 0 & $15.7 \pm 3.1 \mathrm{c}$ & $16.4 \pm 2.3 \mathrm{c}$ & $42.6 \pm 4.8 \mathrm{c}$ & $62.9 \pm 6.1 \mathrm{~b}$ & $42.3 \pm 3.4 \mathrm{~b}$ & $4.8 \pm 1.4 \mathrm{~d}$ \\
40 & 0 & $15.0 \pm 2.8 \mathrm{c}$ & $15.2 \pm 2.1 \mathrm{c}$ & $45.4 \pm 4.3 \mathrm{c}$ & $63.8 \pm 6.0 \mathrm{~b}$ & $46.2 \pm 3.8 \mathrm{~b}$ & $4.7 \pm 1.4 \mathrm{~d}$ \\
0 & 10 & $13.0 \pm 2.4 \mathrm{c}$ & $20.5 \pm 4.2 \mathrm{~b}$ & $44.3 \pm 4.2 \mathrm{c}$ & $48.5 \pm 5.1 \mathrm{~d}$ & $34.5 \pm 3.7 \mathrm{c}$ & $2.8 \pm 1.5 \mathrm{e}$ \\
0 & 20 & $13.7 \pm 2.9 \mathrm{c}$ & $24.5 \pm 3.8 \mathrm{a}$ & $47.2 \pm 3.8 \mathrm{c}$ & $46.0 \pm 5.2 \mathrm{~d}$ & $36.0 \pm 3.2 \mathrm{c}$ & $2.7 \pm 1.2 \mathrm{e}$ \\
0 & 30 & $13.0 \pm 3.6 \mathrm{c}$ & $27.6 \pm 4.1 \mathrm{a}$ & $47.8 \pm 3.8 \mathrm{c}$ & $47.6 \pm 4.3 \mathrm{~d}$ & $34.0 \pm 2.6 \mathrm{c}$ & $2.8 \pm 1.3 \mathrm{e}$ \\
0 & 40 & $12.0 \pm 2.5 \mathrm{c}$ & $26.2 \pm 4.1 \mathrm{a}$ & $44.6 \pm 3.6 \mathrm{c}$ & $42.8 \pm 3.8 \mathrm{~d}$ & $33.0 \pm 2.8 \mathrm{c}$ & $2.8 \pm 1.2 \mathrm{e}$ \\
40 & 10 & $23.7 \pm 4.5 \mathrm{~b}$ & $18.5 \pm 2.9 \mathrm{~b}$ & $54.0 \pm 3.9 \mathrm{~b}$ & $70.8 \pm 6.2 \mathrm{a}$ & $51.3 \pm 3.5 \mathrm{a}$ & $5.7 \pm 1.2 \mathrm{c}$ \\
40 & 20 & $23.5 \pm 3.8 \mathrm{~b}$ & $20.9 \pm 2.3 \mathrm{~b}$ & $54.0 \pm 4.3 \mathrm{~b}$ & $73.4 \pm 6.2 \mathrm{a}$ & $53.5 \pm 4.8 \mathrm{a}$ & $6.7 \pm 2.3 \mathrm{~b}$ \\
40 & 30 & $33.5 \pm 4.8 \mathrm{a}$ & $18.4 \pm 2.1 \mathrm{~b}$ & $68.4 \pm 6.7 \mathrm{a}$ & $73.7 \pm 5.8 \mathrm{a}$ & $56.6 \pm 4.3 \mathrm{a}$ & $7.5 \pm 2.3 \mathrm{a}$ \\
40 & 40 & $25.7 \pm 4.2 \mathrm{~b}$ & $18.9 \pm 2.2 \mathrm{~b}$ & $55.5 \pm 5.8 \mathrm{~b}$ & $71.8 \pm 5.6 \mathrm{a}$ & $57.3 \pm 4.5 \mathrm{a}$ & $5.4 \pm 2.1 \mathrm{c}$ \\
\hline
\end{tabular}

Values are means ( \pm standard error). Means followed by different letters in the same column are significantly different at $5 \%$ level of probability using Duncan's multiple range test.

Table 2. Influence of foliar application of BAP and $\mathrm{GA}_{3}$ alone and in combinations on physiological parameters* of S. macrocarpon

\begin{tabular}{|c|c|c|c|c|c|c|c|}
\hline $\begin{array}{c}\mathrm{BAP} \\
\left(\mathrm{mg} \cdot \mathrm{dm}^{-3}\right)\end{array}$ & $\begin{array}{c}\mathrm{GA}_{3} \\
\left(\mathrm{mg} \cdot \mathrm{dm}^{-3}\right)\end{array}$ & Chlorophyll a & Chlorophyll b & Carotenoids & $\begin{array}{c}\text { Total } \\
\text { phenolics }\end{array}$ & $\begin{array}{c}\text { Total soluble } \\
\text { sugars }\end{array}$ & $\begin{array}{c}\text { Totals soluble } \\
\text { protein }\end{array}$ \\
\hline 0 & 0 & $19.5 \pm 3.4 \mathrm{f}$ & $10.3 \pm 1.8 \mathrm{c}$ & $7.8 \pm 1.4 \mathrm{e}$ & $4.9 \pm 1.2 \mathrm{e}$ & $34.5 \pm 4.5 \mathrm{e}$ & $28.7 \pm 4.2 \mathrm{f}$ \\
\hline 10 & 0 & $28.7 \pm 3.7 \mathrm{e}$ & $12.2 \pm 1.0 \mathrm{~b}$ & $7.8 \pm 1.4 \mathrm{e}$ & $8.4 \pm 2.2 c$ & $87.8 \pm 7.3 c$ & $38.5 \pm 3.9 d$ \\
\hline 20 & 0 & $32.5 \pm 3.2 \mathrm{~d}$ & $11.6 \pm 1.6 \mathrm{~b}$ & $7.6 \pm 1.3 \mathrm{e}$ & $10.7 \pm 2.1 b$ & $88.5 \pm 7.1 \mathrm{c}$ & $37.4 \pm 3.2 \mathrm{~d}$ \\
\hline 30 & 0 & $32.5 \pm 3.2 \mathrm{~d}$ & $11.6 \pm 1.4 \mathrm{~b}$ & $8.7 \pm 1.7 \mathrm{~d}$ & $12.6 \pm 2.4 b$ & $89.7 \pm 7.2 \mathrm{c}$ & $42.3 \pm 3.5 \mathrm{c}$ \\
\hline 40 & 0 & $38.7 \pm 3.4 \mathrm{c}$ & $11.4 \pm 1.8 b$ & $8.6 \pm 1.9 \mathrm{~d}$ & $12.8 \pm 2.3 b$ & $88.8 \pm 7.2 \mathrm{c}$ & $45.2 \pm 3.8 \mathrm{c}$ \\
\hline 0 & 10 & $24.3 \pm 3.1 \mathrm{e}$ & $12.5 \pm 1.8 b$ & $9.8 \pm 1.9 \mathrm{c}$ & $7.5 \pm 1.8 \mathrm{~d}$ & $65.0 \pm 6.7 \mathrm{~d}$ & $35.5 \pm 3.8 \mathrm{~d}$ \\
\hline 0 & 20 & $24.8 \pm 2.8 \mathrm{e}$ & $11.4 \pm 1.6 \mathrm{~b}$ & $10.8 \pm 2.1 \mathrm{c}$ & $7.6 \pm 1.6 \mathrm{~d}$ & $65.8 \pm 6.4 d$ & $35.6 \pm 3.1 d$ \\
\hline 0 & 30 & $27.6 \pm 2.3 \mathrm{e}$ & $13.5 \pm 2.1 b$ & $10.6 \pm 2.2 \mathrm{c}$ & $7.5 \pm 1.8 \mathrm{~d}$ & $65.4 \pm 6.4 \mathrm{~d}$ & $35.8 \pm 3.1 \mathrm{~d}$ \\
\hline 0 & 40 & $27.7 \pm 2.7 \mathrm{e}$ & $14.5 \pm 2.1 b$ & $10.4 \pm 2.3 c$ & $7.4 \pm 1.7 \mathrm{~d}$ & $63.7 \pm 6.3 d$ & $37.7 \pm 3.3 d$ \\
\hline 40 & 10 & $37.9 \pm 3.3 c$ & $16.5 \pm 2.5 b$ & $13.8 \pm 2.4 \mathrm{~b}$ & $16.4 \pm 2.7 \mathrm{a}$ & $94.9 \pm 7.8 b$ & $53.5 \pm 4.6 b$ \\
\hline 40 & 20 & $45.7 \pm 3.4 b$ & $17.4 \pm 2.3 b$ & $13.5 \pm 2.4 \mathrm{~b}$ & $15.6 \pm 2.8 \mathrm{a}$ & $100.7 \pm 8.5 \mathrm{a}$ & $53.5 \pm 4.7 b$ \\
\hline 40 & 30 & $56.8 \pm 4.2 \mathrm{a}$ & $21.4 \pm 2.6 \mathrm{a}$ & $18.9 \pm 2.2 \mathrm{a}$ & $15.8 \pm 2.9 \mathrm{a}$ & $106.9 \pm 8.6 \mathrm{a}$ & $56.9 \pm 4.7 b$ \\
\hline 40 & 40 & $55.4 \pm 4.3 \mathrm{a}$ & $21.3 \pm 2.6 \mathrm{a}$ & $19.6 \pm 3.1 \mathrm{a}$ & $15.8 \pm 3.1 \mathrm{a}$ & $105.8 \pm 8.8 \mathrm{a}$ & $60.8 \pm 6.5 \mathrm{a}$ \\
\hline
\end{tabular}

Note: see Table 1.

*expressed as $\mathrm{mg} \cdot \mathrm{g}^{-1}$ fresh weight

Foliar application of BAP and $\mathrm{GA}_{3}$ alone and in combinations significantly $(p<0.05)$ influenced moisture, crude protein, crude fat, crude fiber, ash and carbohydrate (Table 3). Foliar application of $\mathrm{BAP}$ and $\mathrm{GA}_{3}$ alone decreased the moisture content of the vegetable (Table 3). However, foliar application of $\mathrm{BAP}$ and $\mathrm{GA}_{3}$ in combination raised the moisture content of vegetable to the same level as control plants. Crude protein slightly responded to an increase in the concentration of BAP and $\mathrm{GA}_{3}$ 
when applied alone but had a dramatic increase when BAP and $\mathrm{GA}_{3}$ were applied in combination, with the highest crude protein content recorded in the $40 \mathrm{mg} \cdot \mathrm{dm}^{-3}$ of BAP and $30-40 \mathrm{mg} \cdot \mathrm{dm}^{-3}$ of $\mathrm{GA}_{3}$ combination. A marginal increment was observed in crude fiber content when the as concentration of BAP and $\mathrm{GA}_{3}$ was increased when applied alone. However, crude fiber did not respond to an increase in the concentration of $\mathrm{BAP}$ and $\mathrm{GA}_{3}$ when applied in combination. Plants treated with foliar application of BAP and $\mathrm{GA}_{3}$ in combination had the highest crude fat content, which is thrice the crude fat content of control plants (Table 3 ). Crude fat did not respond to an increase in the concentration of BAP and $\mathrm{GA}_{3}$ when applied alone. Similarly, plants treated with foliar application of BAP and $\mathrm{GA}_{3}$ in combination had the highest ash content, which is nearly thrice the ash content of control plants. Crude ash did not respond to an increase in the concentration of BAP and $\mathrm{GA}_{3}$ when applied alone (Table 3). The highest carbohydrate content was observed in plants treated with foliar application of $\mathrm{GA}_{3}$ alone, and plants treated with foliar application of $40 \mathrm{mg} \cdot \mathrm{dm}^{-3}$ of BAP and $40 \mathrm{mg} \cdot \mathrm{dm}^{-3}$ of
$\mathrm{GA}_{3}$ in combination had the least carbohydrate (Table 3). Carbohydrate did not respond to an increase in the concentration of BAP when applied alone. Our results agreed with the findings of Pal et al. (2016), who observed an increase in the quantity of chlorophylls from foliar sprays of $\mathrm{GA}_{3}$ alone or in combination with $\mathrm{K}$ in cucumber. Furthermore, the high rate of growth from large number of leaves, shoot height, leaf area, fresh shoot weight and dry weight of plants treated with BAP and $\mathrm{GA}_{3}$ could have made adequate assimilates and mineral elements available for the biosynthesis of chlorophylls and carotenoids. In addition, the study also found that the enhanced nitrogen metabolism could be responsible for soluble proteins in plants treated with $\mathrm{GA}_{3}$ because exogenous $\mathrm{GA}_{3}$ at grain filling significantly increases glutamine synthetase, soluble proteins, free amino acids, endogenous $\mathrm{GA}_{3}$ and nitrogen metabolism in wheat (Yang et al. 2013). Recently, data were presented to establish the improvement in total soluble sugars and antioxidant activity (including phenolics) in cucumber following foliar spray of $\mathrm{GA}_{3}$ alone or in combination with $\mathrm{K}$ (Pal et al. 2016).

Table 3. Influence of foliar application of $\mathrm{BAP}$ and $\mathrm{GA}_{3}$ on proximate content* of $S$. macrocarpon

\begin{tabular}{cccccccc}
\hline $\begin{array}{c}\text { BAP } \\
\left(\mathrm{mg} \cdot \mathrm{dm}^{-3}\right)\end{array}$ & $\begin{array}{c}\mathrm{GA}_{3} \\
\left(\mathrm{mg}^{-} \mathrm{dm}^{-3}\right)\end{array}$ & Moisture & Crude protein & Crude fiber & Crude fat & Ash & Carbohydrate \\
\hline 0 & 0 & $76.3 \pm 8.3 \mathrm{~b}$ & $4.5 \pm 1.6 \mathrm{c}$ & $1.5 \pm 0.4 \mathrm{c}$ & $0.8 \pm 0.2 \mathrm{c}$ & $1.4 \pm 0.6 \mathrm{c}$ & $5.5 \pm 1.6 \mathrm{~d}$ \\
10 & 0 & $78.7 \pm 7.8 \mathrm{~b}$ & $4.9 \pm 1.8 \mathrm{c}$ & $1.7 \pm 0.4 \mathrm{~b}$ & $2.2 \pm 0.4 \mathrm{~b}$ & $1.6 \pm 0.7 \mathrm{~b}$ & $10.9 \pm 2.8 \mathrm{~b}$ \\
20 & 0 & $78.4 \pm 7.2 \mathrm{~b}$ & $5.4 \pm 1.3 \mathrm{~b}$ & $1.8 \pm 0.5 \mathrm{~b}$ & $2.2 \pm 0.8 \mathrm{~b}$ & $1.7 \pm 0.6 \mathrm{~b}$ & $10.6 \pm 2.3 \mathrm{~b}$ \\
30 & 0 & $78.4 \pm 7.5 \mathrm{~b}$ & $5.4 \pm 1.5 \mathrm{~b}$ & $1.8 \pm 0.6 \mathrm{~b}$ & $2.5 \pm 0.8 \mathrm{~b}$ & $1.8 \pm 0.8 \mathrm{~b}$ & $10.1 \pm 3.2 \mathrm{~b}$ \\
40 & 0 & $78.7 \pm 7.1 \mathrm{~b}$ & $5.6 \pm 1.5 \mathrm{~b}$ & $1.8 \pm 0.3 \mathrm{~b}$ & $2.4 \pm 0.4 \mathrm{~b}$ & $2.0 \pm 0.4 \mathrm{~b}$ & $9.5 \pm 1.9 \mathrm{~b}$ \\
0 & 10 & $64.2 \pm 6.4 \mathrm{c}$ & $4.4 \pm 1.5 \mathrm{c}$ & $2.0 \pm 0.5 \mathrm{~b}$ & $0.6 \pm 0.1 \mathrm{c}$ & $1.7 \pm 0.5 \mathrm{~b}$ & $27.1 \pm 3.5 \mathrm{a}$ \\
0 & 20 & $64.4 \pm 6.7 \mathrm{c}$ & $4.6 \pm 1.7 \mathrm{c}$ & $2.5 \pm 0.4 \mathrm{a}$ & $0.8 \pm 0.1 \mathrm{c}$ & $1.7 \pm 0.6 \mathrm{~b}$ & $25.9 \pm 4.3 \mathrm{a}$ \\
0 & 30 & $65.4 \pm 5.8 \mathrm{c}$ & $4.5 \pm 1.6 \mathrm{c}$ & $2.6 \pm 0.6 \mathrm{a}$ & $0.8 \pm 0.3 \mathrm{c}$ & $1.8 \pm 0.8 \mathrm{~b}$ & $24.9 \pm 5.3 \mathrm{a}$ \\
0 & 40 & $65.5 \pm 5.6 \mathrm{c}$ & $5.1 \pm 1.9 \mathrm{~b}$ & $2.6 \pm 0.8 \mathrm{a}$ & $0.9 \pm 0.2 \mathrm{c}$ & $1.8 \pm 0.8 \mathrm{~b}$ & $24.5 \pm 5.2 \mathrm{a}$ \\
40 & 10 & $82.5 \pm 5.4 \mathrm{a}$ & $5.5 \pm 1.9 \mathrm{~b}$ & $1.8 \pm 0.7 \mathrm{~b}$ & $2.9 \pm 0.3 \mathrm{a}$ & $2.4 \pm 0.7 \mathrm{a}$ & $4.9 \pm 1.5 \mathrm{c}$ \\
40 & 20 & $83.5 \pm 5.2 \mathrm{a}$ & $5.5 \pm 1.7 \mathrm{~b}$ & $1.8 \pm 0.8 \mathrm{~b}$ & $2.8 \pm 0.4 \mathrm{a}$ & $2.4 \pm 0.7 \mathrm{a}$ & $4.0 \pm 1.6 \mathrm{c}$ \\
40 & 30 & $83.6 \pm 6.4 \mathrm{a}$ & $6.2 \pm 1.3 \mathrm{a}$ & $1.8 \pm 0.8 \mathrm{~b}$ & $2.8 \pm 0.4 \mathrm{a}$ & $2.6 \pm 0.6 \mathrm{a}$ & $3.0 \pm 1.3 \mathrm{e}$ \\
40 & 40 & $84.8 \pm 6.4 \mathrm{a}$ & $6.2 \pm 1.8 \mathrm{a}$ & $1.8 \pm 0.5 \mathrm{~b}$ & $2.8 \pm 0.5 \mathrm{a}$ & $2.6 \pm 0.5 \mathrm{a}$ & $1.8 \pm 0.4 \mathrm{f}$ \\
\hline
\end{tabular}

Note: see Table 1;

*expressed as mg $100 \mathrm{~g}^{-1}$ dry weight 
Table 4. Influence of BAP and $\mathrm{GA}_{3}$ applied alone and in combination on mineral composition* of $S$. macrocarpon leaves

\begin{tabular}{ccccccccc}
\hline $\begin{array}{c}\text { BAP } \\
\left(\mathrm{mg} \cdot \mathrm{dm}^{-3}\right)\end{array}$ & $\begin{array}{c}\mathrm{GA}_{3} \\
\left(\mathrm{mg} \cdot \mathrm{dm}^{-3}\right)\end{array}$ & Sodium & Potassium & Phosphorus & Magnesium & Calcium & Zinc & Iron \\
\hline 0 & 0 & $25.3 \pm 4.5 \mathrm{e}$ & $38.7 \pm 3.1 \mathrm{c}$ & $4.6 \pm 1.3 \mathrm{~d}$ & $6.4 \pm 2.1 \mathrm{f}$ & $45.6 \pm 4.5 \mathrm{c}$ & $9.4 \pm 2.3 \mathrm{~d}$ & $3.8 \pm 1.2 \mathrm{~d}$ \\
10 & 0 & $32.6 \pm 4.1 \mathrm{c}$ & $45.9 \pm 4.2 \mathrm{a}$ & $6.7 \pm 1.2 \mathrm{c}$ & $8.4 \pm 2.2 \mathrm{e}$ & $51.5 \pm 4.8 \mathrm{~b}$ & $13.4 \pm 2.6 \mathrm{c}$ & $4.8 \pm 1.2 \mathrm{c}$ \\
20 & 0 & $38.5 \pm 4.2 \mathrm{c}$ & $45.8 \pm 4.1 \mathrm{a}$ & $9.3 \pm 2.3 \mathrm{c}$ & $12.5 \pm 1.8 \mathrm{~d}$ & $54.6 \pm 4.9 \mathrm{~b}$ & $16.8 \pm 2.3 \mathrm{~b}$ & $7.5 \pm 1.2 \mathrm{~b}$ \\
30 & 0 & $45.3 \pm 4.2 \mathrm{~b}$ & $45.7 \pm 4.2 \mathrm{a}$ & $10.6 \pm 2.3 \mathrm{~b}$ & $13.7 \pm 2.4 \mathrm{~d}$ & $59.8 \pm 5.1 \mathrm{~b}$ & $18.6 \pm 2.2 \mathrm{~b}$ & $9.5 \pm 1.1 \mathrm{~b}$ \\
40 & 0 & $46.8 \pm 4.3 \mathrm{~b}$ & $46.8 \pm 4.1 \mathrm{a}$ & $14.2 \pm 3.4 \mathrm{~b}$ & $21.8 \pm 2.2 \mathrm{~b}$ & $58.8 \pm 4.8 \mathrm{~b}$ & $17.0 \pm 2.4 \mathrm{~b}$ & $9.3 \pm 1.3 \mathrm{~b}$ \\
0 & 10 & $26.5 \pm 2.8 \mathrm{~d}$ & $40.5 \pm 3.8 \mathrm{~b}$ & $5.2 \pm 1.5 \mathrm{c}$ & $6.8 \pm 1.3 \mathrm{e}$ & $53.8 \pm 4.8 \mathrm{~b}$ & $12.4 \pm 2.5 \mathrm{c}$ & $4.7 \pm 1.4 \mathrm{c}$ \\
0 & 20 & $29.5 \pm 2.6 \mathrm{~d}$ & $41.8 \pm 3.6 \mathrm{~b}$ & $7.2 \pm 2.2 \mathrm{c}$ & $8.7 \pm 1.2 \mathrm{e}$ & $57.8 \pm 5.5 \mathrm{~b}$ & $13.5 \pm 2.5 \mathrm{c}$ & $4.9 \pm 0.7 \mathrm{c}$ \\
0 & 30 & $33.6 \pm 2.9 \mathrm{c}$ & $42.8 \pm 3.2 \mathrm{~b}$ & $10.8 \pm 2.2 \mathrm{~b}$ & $12.5 \pm 3.4 \mathrm{~d}$ & $56.9 \pm 5.6 \mathrm{~b}$ & $11.7 \pm 2.4 \mathrm{c}$ & $5.3 \pm 0.8 \mathrm{c}$ \\
0 & 40 & $34.4 \pm 2.9 \mathrm{c}$ & $43.6 \pm 3.2 \mathrm{~b}$ & $14.6 \pm 2.6 \mathrm{~b}$ & $17.8 \pm 2.5 \mathrm{c}$ & $59.4 \pm 5.7 \mathrm{~b}$ & $12.9 \pm 2.6 \mathrm{c}$ & $5.6 \pm 1.1 \mathrm{c}$ \\
40 & 10 & $36.2 \pm 3.2 \mathrm{c}$ & $47.8 \pm 4.2 \mathrm{a}$ & $14.6 \pm 3.3 \mathrm{~b}$ & $19.9 \pm 2.5 \mathrm{c}$ & $58.8 \pm 5.8 \mathrm{~b}$ & $20.5 \pm 2.6 \mathrm{a}$ & $13.7 \pm 2.3 \mathrm{a}$ \\
40 & 20 & $45.8 \pm 4.1 \mathrm{~b}$ & $46.9 \pm 4.1 \mathrm{a}$ & $18.3 \pm 2.5 \mathrm{a}$ & $24.6 \pm 3.4 \mathrm{~b}$ & $63.5 \pm 5.8 \mathrm{a}$ & $21.5 \pm 2.7 \mathrm{a}$ & $12.6 \pm 2.4 \mathrm{a}$ \\
40 & 30 & $50.9 \pm 4.8 \mathrm{a}$ & $43.8 \pm \mathrm{b} 4.2$ & $18.9 \pm 2.6 \mathrm{a}$ & $23.9 \pm 3.2 \mathrm{~b}$ & $68.9 \pm 5.3 \mathrm{a}$ & $22.6 \pm 2.8 \mathrm{a}$ & $14.9 \pm 3.1 \mathrm{a}$ \\
40 & 40 & $50.8 \pm 4.6 \mathrm{a}$ & $41.8 \pm 3.8 \mathrm{~b}$ & $18.3 \pm 2.5 \mathrm{a}$ & $28.6 \pm 3.1 \mathrm{a}$ & $69.4 \pm 5.7 \mathrm{a}$ & $22.4 \pm 2.6 \mathrm{a}$ & $14.8 \pm 2.8 \mathrm{a}$ \\
\hline
\end{tabular}

Note: see Table 1 ; *expressed as $\mathrm{mg} \cdot 100 \mathrm{~g}^{-1}$ dry weight

Mineral elements absorption responded to foliar application of BAP and $\mathrm{GA}_{3}$ alone and in combination (Table 4). Leaf Na, P and $\mathrm{Mg}$ increased as the concentration of BAP was increased; the three mineral elements rose marginally when the concentration of $\mathrm{GA}_{3}$ when applied and in combination with BAP was increased. Foliar application of BAP alone favored absorption of leaf $\mathrm{K}$ comparable to lower doses of $\mathrm{BAP}$ and $\mathrm{GA}_{3}$ applied in combination. The highest quantities of leaf $\mathrm{Ca}, \mathrm{Zn}$ and $\mathrm{Fe}$ were observed when BAP and $\mathrm{GA}_{3}$ were applied in combination.

However, the three mineral elements did not respond to $\mathrm{BAP}$ and $\mathrm{GA}_{3}$ alone (Table 4). The content of mineral elements in treated plants was higher compared with untreated plants because of their fast growth rate (Table 1), which promotes rapid acquisition of the essential mineral elements for growth from the soil to support various plants' metabolism. Foliar application of $\mathrm{GA}_{3}$ alone and in combination with $\mathrm{K}$ improves leaf $\mathrm{N}$ and $\mathrm{P}$ by $30 \%$ in cucumber (Pal et al. 2016). Also, Saddon and Al-Zubaidy (2017) reported an improvement in the content of N, $\mathrm{P}$, and $\mathrm{K}$ in maize grain after the foliar application of $\mathrm{GA}_{3}$. Exogenous BAP has been reported to stimulate the mobilization of photoassimilates and mineral nutrients and increase the activity of the chloroplast (Di Benedetto et al. 2015).
Plant hormones are produced naturally by plants and are essential for regulating their own growth. They act by controlling or modifying plant growth processes, such as formation of leaves and flowers, elongation of stems, development and ripening of fruit (Liu et al. 2016). In modern agriculture, people have established the benefits of extending the use of plant hormones to regulate growth of other plants. When natural or synthetic substances are used in this manner, they are called plant growth regulators (PGR). The application of PGR in agriculture has started in the 1930s in the United States (Liu et al. 2016). From the regulatory control perspective, PGRs are classified under pesticides. The same classification applies internationally under both the Codex systems and competent authorities of developed countries (Liu et al. 2016; Shan et al. 2015). Consequently, the use of PGRs are not allowed in organic farming but allowed in conventional agriculture.

\section{CONCLUSION}

Foliar application of BAP and $\mathrm{GA}_{3}$ alone and in combinations enhanced growth, physiological activities, proximate and mineral element contents of S. macrocarpon. In addition, foliar application of the two PGRs increased the content of bioactive 
compounds such as phenolics and carotenoids, which are extra nutritional constituents that have protective effects against cardiovascular diseases and cancer. The two PGRs (BAP and $\mathrm{GA}_{3}$ ) are safe for use on vegetable and approved by the joint committee of FAO and WHO on pesticide safety. However, further research on $\mathrm{BAP}$ and $\mathrm{GA}_{3}$ residues in the vegetable should be conducted to ensure the compliance with maximum residue limits of pesticides. To boost the quantitative and qualitative yields of the vegetable, we recommend the foliar application of $40 \mathrm{mg} \cdot \mathrm{dm}^{-3}$ of BAP and $30 \mathrm{mg} \cdot \mathrm{dm}^{-3}$ of $\mathrm{GA}_{3}$ in combination at 2 and 4 weeks after transplanting for the growers. Finally, PGRs are a group of chemicals for controlling and enhancing the natural plant growth processes to better meet the requirements of food supply in general. Mechanisms are in place under the Codex system to oversee residues of pesticides (including PGRs) in food for setting standards and public health protection.

\section{REFERENCES}

Adebooye O.C., Opabode J.T. 2004. Status of conservation of the indigenous leaf vegetables and fruits of Africa. African Journal Biotechnology 3: 700-705.

AOAC 1990. Official methods of analysis, $15^{\text {th }}$ ed. Association of Official Analytical Chemists. Washington, USA.

AOAC 1999. Official methods of analysis, $16^{\text {th }}$ ed. Association of Official Analytical Chemists. Washington, USA.

Aslam M., Sultana B., Anwar F., Munir H. 2016. Foliar spray of selected plant growth regulators affected the biochemical and antioxidant attributes of spinach in a field experiment. Turkish Journal of Agriculture and Forestry 40: 136-145. DOI: 10.3906/tar-1412-56.

Ayyub C.M., Manan A., Pervez M.A., Ashraf M.I., Afzal M., Ahmed S. et al. 2013. Foliar feeding with Gibberellic acid $\left(\mathrm{GA}_{3}\right)$ : A strategy for enhanced growth and yield of Okra (Abelmoschus esculentus L. Moench.). African Journal Agricultural Research 8(25): 3299-3302. DOI: 10.5897/ajar12.409.

Bradford M.M. 1976. A rapid and sensitive method for the quantitation of microgram quantities of protein utilizing the principle of protein-dye binding. Analytical Biochemistry 72: 248-254. DOI: 10.1016/0003-2697(76)90527-3.
Coro M., Araki A., Rattin J., Miravé P., Di Benedetto A. 2014. Lettuce and celery responses to both BAP and PBZ related to the plug cell volume. American Journal of Experimental Agriculture 4(10): 11031119. DOI: 10.9734/ajea/2014/10096.

Di Benedetto A., Galmarini C., Tognetti J. 2013. Changes in leaf size and in the rate of leaf production contribute to cytokinin-mediated growth promotion in Epipremnum aureum L. cuttings. Journal of Horticultural Science and Biotechnology 88(2): 179-186. DOI: 10.1080/14620316.2013.11512954.

Di Benedetto A., Galmarini C., Tognetti J. 2015. Exogenous cytokinin promotes Epipremnum aureum L. growth through enhanced dry weight assimilation rather than through changes in partitioning. American Journal of Experimental Agriculture 5(5): 419434. DOI: 10.9734/ajea/2015/13398.

Di Matteo J., Rattin J., Di Benedetto A. 2015. Increase of spinach growth through the use of larger plug cell volume and an exogenous BAP spray. American Journal of Experimental Agriculture 6(6): 372-383. DOI: 10.9734/ajea/2015/14979.

Haliński Ł.P., Paszkiewicz M., Gołębiowski M., Stepnowski P. 2012. The chemical composition of cuticular waxes from leaves of the gboma eggplant (Solanum macrocarpon L.). Journal of Food Composition and Analysis 25(1): 74-78. DOI: 10.1016/j.jfca.2011.06.004.

Julkunen-Tiitto R. 1985. Phenolic constituents in the leaves of Northern willows: methods for the analysis of certain phenolics. Journal of Agricultural and Food Chemistry 33: 213-217. DOI: 10.1021/jf00062a013.

Kumar A., Biswas T.K., Singh N., Lal E.P. 2014. Effect of gibberellic acid on growth, quality and yield of tomato (Lycopersicum esculentum Mill). Journal of Agricultural and Veterinary Science 7(7): 28-30.

Lichtenthaler H.K., Wellburn A.R. 1985. Determinations of total carotenoids and chlorophylls $a$ and $b$ of leaf extracts in different solvents. Biochemical Society Transactions 11: 591-592. DOI: 10.1042/bst0110591.

Liu S., Huang X., He H., Jin Q., Zhu G. 2016. Evaluation of selected plant growth regulators and fungicide residues in fruits for dietary risk assessment. $\mathrm{Hu}-$ man and Ecological Risk Assessment 22: 13861395. DOI: 10.1080/10807039.2016.1185357.

Oboh G., Ekperigin M.M., Kazeem M.I. 2005. Nutritional and haemolytic properties of eggplants ( $\mathrm{So}$ lanum macrocarpon) leaves. Journal of Food Composition and Analysis 18(2-3): 153-160. DOI: 10.1016/j.jfca.2003.12.013. 
Opabode J.T., Adebooye O.C. 2005. Application of biotechnology for the improvement of Nigerian indigenous leaf vegetables. African Journal of Biotechnology 4(3): 138-142.

Owojori S.A. 2017. Growth and physiological responses of Solanum macrocarpon to external application of 6-benzylaminopurine and gibberrellic acid. B. Agric thesis. Obafemi Awolowo University, Ile-Ife, Nigeria, $38 \mathrm{p}$.

Pal P., Yadav K., Kumar K., Singh N. 2016. Effect of gibberellic acid and potassium foliar sprays on productivity and physiological and biochemical parameters of parthenocarpic cucumber cv. 'Seven Star $F_{1}$ '. Journal of Horticultural Research 24(1): 93-100. DOI: 10.1515/johr-2016-0011.

Pearson D. 1976. The chemical analysis of foods, $7^{\text {th }}$ ed. Churchill Livingstone, UK, pp. 7-11.

Saddon N., Al-Zubaidy N.A. 2017. Effect of gibberellic acid on growth, yield, and chemical composition of corn (Zea mays L.): A review. Journal Purity, Utility Reaction and Environment 6(3): 14-29.
Schippers R.R. 2000. African indigenous vegetables. An overview of the cultivated species. University of Greenwich, Natural Resources Institute/ACP-EU, UK, 214 p.

Shan L.S., Tao L., Jie S.L., Xin L., Fang Y., Cheng L.H. 2015. Dietary exposure and risk assessment of plant growth regulator residues in vegetables. Journal of Food Safety and Quality 6: 4942-4948.

Taiz L., Zeiger E. 2002. Plant physiology, $3^{\text {rd }}$ ed. Sinauer Associates, Massachusetts, USA, 690 p.

Yamaguchi S. 2008. Gibberellin metabolism and its regulation. Annual Review of Plant Biology 59(1): 225251. DOI: 10.1146/annurev.arplant.59.032607.092804.

Yang W.T., Cai Y., Ni Y., Li J., Guo J., Peng D., Yang D., Yin Y., Wang Z. 2013. Effects of exogenous abscisic acid and gibberellic acid on filling process and nitrogen metabolism characteristics in wheat grains. Australian Journal of Crop Science 7(1): 58-65.

Yemm E.W., Willis A.J. 1954. The estimation of carbohydrates in plant extracts by anthrone. Biochemical Journal 57: 508-514. DOI: 10.1042/bj0570508. 